\title{
1 Pleistocene deep sea ostracods from the Bering Sea (IODP
}

2 Expedition 323)

3 Carlos A. Alvarez Zarikian

4 International Ocean Discovery Program \& Department of Oceanography, Texas A\&M University, College Station,

5 Texas 77845, U.S.A.

6 Abstract

7 The study presents the first Pleistocene (0-1.9 Ma) record of deep sea ostracods from the Bering

8 Sea, derived primarily from Integrated Ocean Drilling Program Expedition 323, Site U1344

$9\left(59^{\circ} 3.0^{\prime} \mathrm{N}, 179^{\circ} 12.2^{\prime} \mathrm{W}, 3171 \mathrm{~m}\right.$ of water depth). Deep sea ostracod abundances in the Bering Sea sediments are some of the lowest that have been recorded in bathyal marine environments $(<1$

11 specimen per sediment gram). In comparison, benthic foraminifera are several orders of

12 magnitude more abundant in the same samples. The humble ostracod assemblage at Site U1344

13 is predominantly composed of deep water species Krithe sawanensis, Fallacihowella sp. A,

14 Cytheropteron spp., Eucytherura sp., Argilloecia toyamaensis, and Bradleya mesembrina. Less

15 abundant taxa include Munseyella melzeri, Munseyella ristveti, Cluthia sp., Robertsonites hanaii, 16 and Microcythere mediostriata. Some of these taxa (e.g. Fallacihowella sp. A, Bradleya

17 mesembrina, Microcythere mediostriata) are reported for the first time in the North Pacific. The 18 predominance of the genera Krithe, Fallacihowella, Cytheropteron and Argilloecia indicates cold, ventilated bottom waters. The deep Bering Sea ostracod assemblage shares many common and closely related species with slope faunas from the Gulf of Alaska, the Okhotsk Sea, the

21 Arctic Ocean, and even the subpolar North Atlantic. A few continental shelf ostracods, such as

22 species of Munseyella and Robertsonites, are present at Sites U1344 and U1343, in the northern

23 slope of the Aleutian Basin. The presence of shallow water ostracods at the Bering Sea slope 
24 sites is possibly explained by sea ice rafting. Exceptionally low ostracod abundance in the U1344

25 record did not permit evaluating links between ostracod faunas and paleoceanographic

26 conditions; however, an increase in ostracod occurrences throughout the middle Pleistocene at

27 Site U1344 appears to correlate with general sea ice expansion in the Bering Sea. High primary

28 surface productivity, high food flux and high sedimentation rates are considered to be the main

29 factors diluting or suppressing deep sea ostracods in the Bering Sea, suggesting that ostracods

30 may prefer living in more oligotrophic deep water environments with well oxygenated waters

31 and moderate food supply. 


\section{Introduction}

The majority of the ostracod studies from high latitude North Pacific marginal seas have focused on Miocene to Pleistocene sequences in and around Japan, the Japan Sea (e.g., Okada, 1979; Cronin and Ikeya, 1987; Ikeya et al., 1992; Ikeya and Cronin, 1993; Ozawa, 2003; Ozawa et al., 2004; Ozawa and Kamiya, 2005; Ozawa, 2009; Irizuki et al., 2007, 2009; Iwatani et al.,

37 2012; Yamada et al., 2002), modern sediments in the Okhotsk Sea (Ozawa, 2004; Ozawa and 38 Tsukawaki, 2008), and Quaternary sediments in the Gulf of Alaska (Brouwers, 1988, 1990, 1993, 1994). Yet, with the exception of a recent study of modern benthic ostracods from the

40 northern Bering and Chukchi Sea shelves (Gemery et al., 2013), very little is known about ostracods from the Bering Sea, in particular bathyal and abyssal faunas. One potential reason for the lack of information on deep sea ostracods from this region is their very low abundance in biosiliceous-rich sediments that characterize the North Pacific Ocean. Sediment in the deep Bering Sea generally lacks abundant carbonate microfossils because the seafloor is below the carbonate compensation depth (CCD) in most regions. The lysocline and the CCD over the continental slope of the Bering Sea are documented at depths of 2000 and $3800 \mathrm{~m}$, respectively (Chen et al., 2005). This study uses core samples derived from sites drilled during Integrated Ocean Drilling Program (IODP) Expedition 323 to examine and document the abundance, taxonomic composition, and paleoenvironmental significance of deep sea ostracod assemblages from the Bering Sea.

IODP Expedition 323 sailed into the Bering Sea in 2009 with the aim at studying for the first time the sedimentary and paleoceanographic history of this marginal sea over the past $5 \mathrm{Ma}$. Seven sites (U1339 to U1345) distributed on a depth transect ranging from 819 to 3173 and 
54 covering three different regions (Umnak Plateau, Bowers Ridge, and the Bering slope region)

55 were successfully drilled during the expedition (Figure 1, Table 1)(Takahashi et al., 2011).

The cored sedimentary sequences at the Bering Sea sites are composed of terrigenous,

57 glaciomarine, and biogenic components that capture the spatial and temporal evolution of the

58 Bering Sea through the Pliocene and Pleistocene (Takahashi et al, 2011). Terrigenous sediment

59 are mostly made up of angular siliciclastics and volcaniclastics, whereas biogenic sediment

60 predominantly contain siliceous microfossils (diatoms, radiolarians, silicoflagellates, ebridians),

61 and a much lower amount of organic (dinoflagellates), and calcareous microfossils (nannofossils,

62 planktonic and benthic foraminifers, and ostracods) (Takahashi et al, 2011).

\section{Study area}

The Bering Sea is the third largest marginal sea in the world and one of the world's most

66 productive regions, supporting high seasonal primary productivity exceeding $1 \mathrm{gC} \mathrm{m}^{-2} \mathrm{~d}^{-1} \mathrm{during}$

67 the spring bloom (Brown et al., 2011; Springer et al., 1996), and exhibiting sediment with

68 profuse siliceous microfossils, and very high sedimentation rates (Takahashi et al., 2011; Aiello

69 and Ravelo, 2012). Approximately one half of the Bering Sea is a shallow (0-200 m) neritic

70 environment, with the majority of the continental shelf spanning the eastern side of the basin off

71 Alaska from Bristol Bay to the Bering Strait (Figure 1). The northern continental shelf is

72 seasonally ice covered, and little ice forms over the deep southwest areas. In addition to the shelf

73 regions, two significant topographic highs have better carbonate preservation than the deep

74 basins: Shirshov Ridge, which extends south of the Koryak Range in eastern Siberia; and Bowers

75 Ridge, which extends $300 \mathrm{~km}$ northwest from the Aleutian Island arc. To the south of the Bering 
76 Sea is the Aleutian Basin, a vast plain $\sim 3850 \mathrm{~m}$ deep, with occasional gradually sloping

77 depressions as deep as $4150 \mathrm{~m}(\mathrm{Hood}, 1983)$.

78 Three major rivers flow into the Bering Sea: the Kuskokwim and Yukon rivers drain

79 central Alaska, and the Anadyr River drains parts of eastern Siberia. Surface water circulation in

80 the Bering Sea is dominated by an anticlockwise gyre (the Bering Sea Gyre) along the Bering

81 Slope, contributing to the main flow of the Bering Slope Current (BSC, Stabeno et al., 1999).

82 Water exchange between the Bering Sea and the North Pacific Ocean takes place along the 83 several paths between the Aleutian Islands (generally between 1 and $4 \mathrm{~km}$ water depth).

\section{Materials and Methods}

This study focuses on IODP Site U1344 in the center of the northern Bering Sea slope margin, but also examines selected samples from Sites U1339, U1341, U1342, and U1343

89 (Figure 1, Table 1). Site U1344 $\left(59^{\circ} 3.0^{\prime} \mathrm{N}, 179^{\circ} 12.2^{\prime} \mathrm{W}, 3171 \mathrm{~m}\right.$ of water depth) is located on a 90 small summit of a canyon interfluve and $\sim 10-15 \mathrm{~km}$ southeast of Pervenets Canyon, a large 91 submarine canyon that deeply, and widely incises the Beringian continental slope. During glacial

92 times and low sea level, the head of Pervenets Canyon is believed to have been one of the outfall 93 locations for the Anadyr River, which presently drains the Russian northeast and enters the 94 Bering Sea at the Gulf of Anadyr. Site U1344 is situated in an area of very high biological 95 surface productivity, high organic carbon accumulation at the seafloor (Springer et al., 1996), 96 and close to the maximum extent of present day seasonal sea ice cover (Takahashi et al., 2011). 
Five holes were cored at Site U1344 to various depths below seafloor (Takahashi et al.,

98 2011). Core samples examined in this study are primarily from Hole U1344A, the deepest hole,

99 which extends from the seafloor down to $746.6 \mathrm{mbsf}$ (meters below the seafloor). Based on

100 shipboard biostratigraphic and magnetostratigraphic data, the cored section in Hole U1344A

101 covers the past $\sim 1.9$ million years (Takahashi et al., 2011). The sample resolution for the present

102 study averages $4.6 \mathrm{~m}$ (or $\sim 11.7 \mathrm{ky}$ ) throughout the section.

103

104

105

106

107

108

109

110

111

112

113

114 from the Bering shelf (Takahashi et al., 2011). At U1339, the study focuses on an interval from

11566.4 to $84.5 \mathrm{mbsf}$ where samples were previously examined for benthic foraminifera. At the

116 other sites, I re-examined ostracod specimens picked during routine shipboard examination for

117 benthic foraminifera but that were left in open nomenclature in the Expedition Reports

118 (Takahashi et al., 2011). 
120 Expedition 323 were also examined for the presence of ostracods. These samples are different

121 from ordinary coretop samples in that they represent the soft and fluffy sediment at the

122 sediment/water interface. Mudline samples were dyed with Rose Bengal soon after core

123 recovery, and allowed soaking for 24 hours before sieving and drying. The size and successful

124 recovery of mudline samples varied from hole to hole and from site to site as a result of the 125 coring process, hole-to-hole stratigraphic correlation strategies, and sediment type.

127 3.3. Age models 133 shown in Table 1.

137 were dried and weighed, and later washed with tap water over a $63 \mu \mathrm{m}$ sieve. Once dry, the 138 coarse fractions $(>63 \mu \mathrm{m})$ were weighed before picking. All ostracods were picked from the $139>125 \mu \mathrm{m}$ sediment size fractions with a fine, damp brush under a light microscope and placed on 
140 slides, where they were identified and counted. While single valves were counted as one

141 specimen, complete carapaces were enumerated as two valves. For ostracod identifications, I

142 followed the taxonomy provided in Brouwers (1990, 1993, 1994), Ozawa and Tsukawaki (2008),

143 and other ostracod works from the Okhotsk Sea and the North Pacific. Taxonomic nomenclature

144 follows the World Ostracod Database (Brandão et al., 2014). Selected specimens were coated

145 using standard Pd-Au coating techniques, and digitally imaged using an FEI Quanta $600 \mathrm{FE}$

146 scanning electron microscope.

\section{Results and Discussion}

A total of twenty one taxa were identified from one hundred and eighty two core samples

150 from Site U1344, eighty nine core samples from Site U1339, and mudline samples from Sites

151 U1339, U1342, U1343 and U1344. Among all of these samples, only 44 contained ostracods. In

152 addition, all ostracods picked from core catcher samples during Expedition 323 were re-

153 examined and their taxonomy revised. The overall assemblage includes a mixture of mainly

154 upper and lower slope species (Table 2). Representative taxa are illustrated in Plates 1 and 2.

155 Absolute ostracod abundance was very low, four specimens per sample or less $(<1$

156 specimen per sediment gram) at all sites. The exceptionally low and sporadic ostracod density in 157 the Bering Sea samples, in particular in the long record at Site U1344 (Figure 2), prevented any 158 reliable statistical analyses of the data and any potential linking of the ostracod faunas to 159 paleoceanographic conditions or climatic periods (e.g., glacial or interglacial periods). Despite

160 the low abundance, ostracod preservation was generally good (translucid valves), and about half 161 of the specimens found are articulated carapaces. Poorly preserved specimens were few and they 
162 exhibited white to yellowish valves, and showed some signs of dissolution or recrystallization.

163 Dark yellow specimens were generally observed in the older ( $>1.2 \mathrm{Ma})$ part of Site U1344

164 record.

165

166

167

168

169

170

171

172

173

174

175

176

177

178

179

180 181 patterns.

\subsection{Ostracod assemblage composition}

The most common genera in the Bering Sea samples are Krithe, Fallacihowella, Cytheropteron and Argilloecia. These taxa are known to prefer cold and well ventilated bottom waters, and moderate to ample food supply (Didié et al., 2002; Ayress et al., 2004; Mazzini, 2005; Alvarez Zarikian et al., 2009; Poirier et al., 2012, Yasuhara et al., 2012). They all have global distribution and are found in all the world oceans. In the central Arctic Ocean, Krithe and Cytheropteron have been associated with the interglacial conditions, and possibly deep water convection as is found in the Norwegian-Greenland Sea (Poirier et al., 2012; Cronin et al., 2013).

In the North Atlantic, Cytheropteron is associated with deglacial transitions and fresh food supply. Argilloecia and Henryhowella (a related genus of Fallacihowella) are associated with interglacials and interstadials (Cronin et al., 1999; Alvarez Zarikian et al., 2009). In the South Atlantic sector of the Southern Ocean, Krithe was highly abundant during interglacials MIS 1 and 5 and was almost absent during glacials MIS 2-4, while Henryhowella was dominant during the glacial MIS 2-4 and was less abundant during the interglacial MIS 1 and 5 (Yasuhara et al., 2009). These two genera do not co-occur in the same samples in the Bering Sea, but ostracods are so rare in the deep Bering Sea that it is not possible to establish any paleoenvironmental

The ostracod assemblage at Site U1344 includes Krithe sawanensis Hanai, Fallacihowella sp. A, Eucytherura sp., Cytheropteron hanaii Ishizaki, Cytheropteron spp., 
184 185

Argilloecia toyamaensis Ishizaki and Irizuki, Bradleya mesembrina Mazzini, Munseyella melzeri Brouwers, Cluthia sp., Microcythere mediostriata (Joy and Clark), Polycope sp. and Loxoconchidea sp. The ostracod assemblage at Site U1339 has a similar taxonomic composition with additional species of Cytheropteron (Tables 2 and 3).

The U1344 data illustrated in Figure 2 show that most samples were barren of ostracods during the early and middle Pleistocene ( $~ 1.9$ to $0.6 \mathrm{Ma})$. Ostracod densities slightly increase during the Late Pleistocene. The slight increase in ostracod peaks at the end of the midPleistocene seems to be synchronous with an increase in cold water and sea ice related diatom species observed at nearby Site U1343 (Teraishi et al., 2014).

Mudline samples also yielded very low ostracod abundances. However, most of the modern specimens represented articulated carapaces, and several of them were stained with Rose Bengal. Stained individuals are considered to have been alive at the time of sampling. Live specimens included Cytheropteron sp. C (Site U1343) and Cytheropteron sp. A (Site U1344). Non-stained specimens of Cytheropteron sp. A and Loxoconchidea sp. were observed in the U1342 mudsample (Bowers Ridge), while Munseyella melzeri, Munseyella ristveti and Robertsonites hanaii were found in core samples from Site U1343.

The Bering Sea ostracod faunas share many common and closely related species with slope faunas from the Gulf of Alaska, the Okhotsk Sea, the Arctic Ocean, and the subpolar North Atlantic. The strong affinity among these faunas is reasonable given the adjacent nature of these marginal seas, slopes and shelves, and the depth connections through the Umnak and Amukta passes in the Aleutian Islands to the east, the Strait of Kamchatka to the west, and the Arctic gateway to the north. 
The presence of a few shallow water (shelf to upper slope) taxa, such as Munseyella and

Robertsonites (Ozawa, 2004), at Sites U1343 and U1344 can be explained by sea ice rafting, which is a well-known mechanism for the distribution of ostracods in high latitude areas, such as the Arctic and North Atlantic (Didié and Bauch, 2000; Stepanova et al., 2003; Alvarez Zarikian et al, 2009) and the Okhotsk Sea (Ozawa, 2004). The presence of ice rafted ostracods at Sites U1343 and U1344 is not surprising because these sites are located along the northern Bering Sea slope, proximal to the maximum extent of the modern seasonal sea ice cover, and under an area of high biological productivity and high sedimentation rates (Springer et al., 1996; Takahashi et al., 2011). During glacial times, sea ice expanded further southward onto the Bering Sea basin. Grain size analysis on the sediments from Site U1343 and U1344, suggested that the clay sized particles at the Bering Sea Slope were delivered mainly from sedimentation processes via icerafting (Aiello and Ravelo, 2012). Moreover, higher sedimentation rates at the Bering Sea Slope sites than at the other Expedition 323 sites was attributed to greater contribution of siliciclastic components to the Bering Sea Slope (Takahashi et al., 2011).

\subsection{Ostracod abundance in the Bering Sea}

Ostracod distribution in the deep sea is primarily controlled by food supply, sediment accumulation rates, and bottom water ventilation (Dingle and Lord, 1990; Corrège, 1993; Ayress et al., 1997; Didié et al., 2002; Ozawa, 2004; Yasuhara and Cronin, 2008; Yasuhara et al, 2009; Alvarez Zarikian, 2013). In eutrophic environments, such as the Bering Sea, critical oxygen levels in the bottom waters can be a major limiting factor for benthic faunal density and diversity (Jorissen et al., 2007), although some organisms, such as some benthic foraminifers, are able to tolerate and even thrive in dysaerobic conditions and take advantage of the ample food supply more effectively than ostracods (Yasuhara et al., 2012). In the Bering Sea samples, calcareous 
229 benthic foraminifer abundances are typically orders of magnitude higher than ostracods (as many

230 as $\sim 300$ to $\leq 1$ ). The exceptionally low ostracod abundance is surprising because the calcareous

231 shells of ostracods and foraminifera exhibit similar size ranges and are usually abundantly

232 preserved in marine sediments. Both groups of organisms are believed to exploit the same food

233 source in the deep sea particulate organic matter that sinks from shallower depths (Gooday,

234 1994; Didié and Bauch, 2000; Cronin and Dwyer, 2003; Yasuhara and Cronin, 2008; Yasuhara

235 et al., 2012).

Site U1344 lies today below the modern oxygen minimum zone (Takahashi et al., 2011),

237 and the ostracod assemblage composition at Site U1344 suggests that the bottom waters at this

238 site are moderately well ventilated. Therefore, it is hypothesized that in the Bering Sea, low

239 ostracod abundance cannot be explained by poor bottom water ventilation alone, but by a

240 combination of other environmental factors. High primary surface productivity and high

241 sedimentation rates of particulate organic matter, diatom frustules, and siliciclastic and

242 volcaniclastic material could be the primary reasons for the low ostracod densities in the deep

243 Bering Sea. However, poor carbonate preservation due to dissolution cannot be discarded.

Low ostracod densities have been recorded at least at another high productivity region in

245 the North Pacific. A recent study on the Shatsky Rise by Yasuhara et al. (2012) has shown that

246 the abundance of benthic foraminifers has a positive relationship with both primary surface

247 productivity and seasonality of productivity. In contrast, the same study showed that ostracod

248 abundance has an inverse relationship at high productivity levels. The Bering Sea ostracod data

249 support the results at the Shatsky Rise and indicate the existence of different responses to

250 environmental factors between ostracods and benthic foraminifers. Comparison of the Bering

251 Sea ostracod data with faunal data from the South Pacific Gyre (Alvarez Zarikian, 2013), one of 
252 the most oligotrophic ocean regions in the world, indicates the preference of ostracods for

253 habitats with moderate food supply and higher oxygen concentrations.

\section{Conclusions}

This study presents the first Pleistocene record of deep sea ostracods from the Bering

257 Sea. Ostracod abundances in the Bering Sea sediments are some of the lowest recorded in

258 bathyal marine environments ( $<1$ specimen per sediment gram). In comparison, benthic

259 foraminifera in the same samples are several orders of magnitude more abundant. The ostracod

260 assemblage at Site U1344 is predominantly composed of deep water species Krithe sawanensis,

261 Fallacihowella sp. A, Cytheropteron spp., Eucytherura sp., Argilloecia toyamaensis, and

262 Bradleya mesembrina. Minor taxa include Munseyella melzeri, Cluthia sp., Robertsonites sp.,

263 and Microcythere mediostriata. Predominance of the genera Krithe, Fallacihowella,

264 Cytheropteron and Argilloecia indicates cold and oxygenated bottom waters. Pleistocene deep

265 sea ostracods in the Bering Sea share many common and closely related species with slope

266 faunas from the northern Japan Sea, the Okhotsk Sea, the Gulf of Alaska, the Arctic Ocean, and

267 the subpolar North Atlantic. The occasional presence of typical shallow water ostracods, such as

268 Munseyella and Robertsonites, at the Bering Sea slope Sites U1344 and U1343 can be explained

269 by sea ice rafting, or may reflect the ability of ostracod species that live in cold water in high

270 latitude seas to migrate and live in deeper waters at more southern high latitudes. No links

271 between ostracod faunas and past oceanographic conditions during the Pleistocene and Holocene

272 were recognized due to exceptionally low ostracod abundance at Site U1344. However, the onset

273 of subtle ostracod peaks in the record coincides with times of sea ice expansion in the Bering Sea 
274 from the middle to the late Pleistocene. Although carbonate dissolution is an important factor in

275 the preservation of calcareous organisms in the Bering Sea, high primary surface productivity,

276 high sedimentation rates and high food flux to the sea bed seem to be the main factors depressing

277 deep sea ostracod densities at the studied sites. Comparison of the Bering Sea ostracod data with

278 other ocean regions indicates that deep sea ostracods may prefer well oxygenated waters in more

279 oligotrophic environments with moderate food supply.

\section{Acknowledgments}

I would like to thank M. Yasuhara, T. Cronin, S.N. Brandão, W.H. Briggs and A.

283 Stepanova for helpful reviews of the manuscript and the ostracod taxonomy; S. Kender for

284 providing SEM images of three species from Site U1343; A. Ulincy for sample processing; and

285 T. Stephens for SEM assistance. This research used samples and/or data provided by the

286 Integrated Ocean Drilling Program (IODP) and collected during IODP Expedition 323. Funding

287 for this research was provided by the Consortium for Ocean Leadership - U.S. Science Support

288 Program and the U.S. National Science Foundation Grant 0963366. The FE-SEM acquisition by

289 the Texas A\&M University Microscopy Imaging Center was supported by National Science

290 Foundation Grant DBI-0116835, the Vice President for Research Office and the Texas

291 Engineering Experiment Station.

\section{References}

294 Aiello, I. and A.C. Ravelo, 2012. Evolution of marine sedimentation in the Bering Sea since the 295 Pliocene. Geosphere, 8(6): 1-23. doi:10.1130/GES00710.1 
296 Alvarez Zarikian, C.A., 2009. Data report: late Quaternary ostracodes at IODP Site U1314

297 (North Atlantic Ocean). In Channell, J.E.T., Kanamatsu, T., Sato, T., Stein, R., Alvarez Zarikian, 298 C.A., Malone, M.J., and the Expedition 303/306 Scientists, Proc. IODP, 303/306: College

299 Station, TX (Integrated Ocean Drilling Program Management International, Inc.).

300 doi:10.2204/iodp.proc.303306.213.2009

301 Alvarez Zarikian, C.A. 2013. Ostracoda in deep ocean Cenozoic paleoceanography: from regions 302 of deep water formation to ultraoligotrophic environments. (Invited Keynote) $17^{\text {th }}$ International 303 Symposium on Ostracoda, Rome, Italy (July 23-26, 2013).

304 Alvarez Zarikian, C.A., Stepanova, A.Y., and Grützner, J., 2009. Glacial-interglacial variability 305 306 in deep sea ostracod assemblage composition at IODP Site U1314 in the subpolar North Atlantic. Mar. Geol., 258(1-4):69-87. doi:10.1016/j.margeo.2008.11.009

Ayress, M., Neil, H., Passlow, V., and Swanson, K., 1997. Benthonic ostracods and deep watermasses: a qualitative comparison of southwest Pacific, Southern and Atlantic Oceans. Palaeogeogr., Palaeoclimatol., Palaeoecol., 131(3-4):287-302. doi:10.1016/S00310182(97)00007-2

Ayress, M.A. P. De Deckker, G.P. Coles, 2004. A taxonomic and distributional survey of marine benthonic Ostracoda off Kerguelen and Heard Islands, South Indian Ocean. Journal of Micropalaeontology, 23: 15-38.

Brandão, S.N., O. Päplow, 2011. New species and occurrences of Bradleya Benson, 1972, Harleya Jellinek \& Swanson, 2003, and Poseidon amicus Benson, 1972 (Ostracoda:

317 Brandão, S. N.; Angel, M. V.; Karanovic, I. (2014) World Ostracoda Database. Accessed at 318 http://www.marinespecies.org/ostracoda on 2014-March.

Briggs, W.M. Jr., 1997. Axelheibergella (Ostracoda, Crustacea), a new genus of marginally septate cladocopid ostracods from the central Arctic Ocean. Journal of Micropalaeontology, 16, 321 109-120.

322 Brouwers, E.M. 1988. Palaeobathymetry on the continental shelf based on examples using ostracoda from the Gulf of Alaska (55-76). In De Deckker, P., J.-P. Colin and J.-P. Peypouquet, 324 Ostracoda in the Earth Sciences, Elsevier, 302 p.

325 Brouwers, 1990. Systematic Paleontology of Quaternary Ostracode Assemblages from the Gulf 326 of Alaska, Part 1 - Families C ytherellidae, Bairdiidae, Cytheridae, Leptocytheridae, 327 Limnocytheridae, Eucytheridae, Krithidae, Cushmanideidae. U.S. Geological Survey 328 Professional Paper 1510, 1-43, 13 plates 
Brouwers, 1993. Systematic Paleontology of Quaternary Ostracode Assemblages from the Gulf of Alaska, Part 2 - Families Trachyleberididae, Hemicytheridae, Loxoconchidae, Paracytherideidae. U.S. Geological Survey Professional Paper 1531, 1-47, 16 plates.

Brouwers, 1994. Systematic Paleontology of Quaternary Ostracode Assemblages from the Gulf of Alaska, Part 3-Family Cytheruridae. U.S. Geological Survey Professional Paper 1544, 1-45, 23 plates.

Brown, Z.W., van Dijken,G.L., Arrigo, K.R., 2011.A reassessment of primary production and environmental change in the Bering Sea. J. Geophys. Res. 116, C08014, http://dx.doi.org/10.1029/2010JC006766.

Caissie, B. E., J. Brigham-Grette, K. T. Lawrence, T. D. Herbert, and M. S. Cook (2010), Last Glacial Maximum to Holocene sea surface conditions at Umnak Plateau, Bering Sea, as inferred from diatom, alkenone, and stable isotope records, Paleoceanography, 25, PA1206, doi:10.1029/2008PA001671.

Chen, R., Y. Meng, R. Wang, D. Hua, and J. Xu, 2005. Oceanographic Records of microorganisms in the Surface Sediments from the Bering and Chukchi Seas, Asian J. Water, Environ. Pollut. 2 (1), 19-26.

Cook, M.S., Keigwin, L.D., and Sancetta, C.A., 2005. The deglacial history of surface and intermediate water of the Bering Sea. Deep-Sea Res., Part II, 52(16-18):2163-2173. doi:10.1016/j.dsr2.2005.07.004

Corrège, T., 1993. The relationship between water masses and benthic ostracod assemblages in the western Coral Sea, Southwest Pacific. Palaeogeogr., Palaeoclimatol., Palaeoecol., 105(34):245-266. doi:10.1016/0031-0182(93)90086-X

Cronin, T. M., and G. S. Dwyer. 2003. Deep sea ostracodes and climatic change. Paleontological Society Papers 9:247-263.

Cronin, T.M. and N. Ikeya. 1987. The Omma-Manganji ostracod fauna (Plio-Pleistocene) of Japan and the zoogeography of circumpolar species. J. Micropalaeontology, 6(2): 65-88.

Cronin, T.M., D.M. DeMartinoa, G.S. Dwyer, J. Rodriguez-Lázaro, 1999. Deep-sea ostracode species diversity: response to late Quaternary climate change, Marine Micropaleontology 37: 231-249

Cronin, T.M., L. Polyak, D. Reed, E.S. Kandiano, R.E. Marzen, E.A. Council, 2013. A 600-ka Arctic sea-ice record from Mendeleev Ridge based on ostracodes. Quaternary Science Reviews 79: $157-167$. 
Didié, C., and Bauch, H.A., 2000. Species composition and glacial-interglacial variations in the ostracode fauna of the northeast Atlantic during the past 200,000 years. Mar. Micropaleontol., 40(1-2):105-129. doi:10.1016/S0377-8398(00)00034-7

Didié, C., Bauch, H.A., and Helmke, J.P., 2002. Late Quaternary deep-sea ostracodes in the polar and subpolar North Atlantic: paleoecological and paleoenvironmental implications.

Palaeogeogr., Palaeoclimatol., Palaeoecol., 184(1-2):195-212. doi:10.1016/S00310182(02)00259-6

Dingle, R.V., and Lord, A.R., 1990. Benthic ostracods and deep water-masses in the Atlantic Ocean. Palaeogeogr., Palaeoecol., Palaeoecol., 80(3-4):213-235. doi:10.1016/00310182(90)90133-R

Gooday, A. 1994. The biology of deep-sea foraminifera: a review of some advances and their applications in paleoceanography. Palaios 9:14-31

Gemery, L., T.M. Cronin, L.W. Cooper, J.M. Grebmeier. 2013. Temporal changes in benthic ostracode assemblages in the Northern Bering and Chukchi Seas from 1976 to 2010. Deep-Sea Research II, 94: 68-79.

Hanai, T., 1957. Studies on the Ostracoda from Japan. Univ. Tokyo, Fac. Sci., Jour., sec. 2, v. IO, pt. 3, p. 431-468, 4 pls.

Hood, D.W. 1983. The Bering Sea, in: Ketchum, B.H. (Ed.), Estuaries and Enclosed Seas, Elsevier, Amsterdam, pp. $337-373$

Ikeya, N., T.M. Cronin. 1993. Quantitative Analysis of Ostracoda and Water Masses around Japan: Application to Pliocene and Pleistocene Paleoceanography. Micropaleontology, 39(3): 263-281.

Ikeya, N., B.-C. Zhou and J.I. Sakamoto. 1992. Modern ostracode fauna from Otsuchi Bay, the Pacific coast of the northeastern Japan. In K. Ishizaki and T. Saito (eds.) Centenary of Japanese Micropaleontology, p. 339-354, Terra Scientific Publishing Company, Tokyo.

Irizuki, T., M. Kusumoto, K. Ishida, Y. Tanaka, 2007. Sea-level changes and water structures between 3.5 and 2.8 Ma in the central part of the Japan Sea Borderland: Analyses of fossil Ostracoda from the Pliocene Kuwae Formation, central Japan; Palaeogeography, Palaeoclimatology, Palaeoecology 245: 421-443

Irizuki, T., H. Taru, K. Taguchi, Y. Matsushima, 2009. Paleobiogeographical implications of inner bay Ostracoda during the Late Pleistocene Shimosueyoshi transgression, central Japan, with significance of its migration and disappearance in eastern Asia. Palaeogeography, Palaeoclimatology, Palaeoecology 271: 316-328. 
Ishizaki, K., 1981. Ostracoda from the East China Sea. Tohoku Univ., Sci. Rep., 2nd ser. (Geol.), v. 51, nos. 1-2, p. 37-65, 1 fig., 2 tables, pls. 8-15.

Iwatani, H., T. Irizuki, H. Hayashi, 2012. Global cooling in marine climates and local tectonic events in Southwest Japan at the Plio-Pleistocene boundary, Palaeogeography, Palaeoclimatology, Palaeoecology 350-352: 1-18

Jellinek, T. and K.M. Swanson, 2003. Report on the taxonomy, biogeography and phylogeny of mostly living benthic Ostracoda (Crustacea) from deep-sea samples (Intermediate Water depths) from the Challenger Plateau (Tasman Sea) and Campbell Plateau (Southern Ocean), New Zealand, Abh. Senckenberg. Naturforsch. Ges, 558: 1-329, 9 Figs., 2 Tab., 107 Pls

Jorissen, F.J., C. Fontanier, E. Thomas. 2007. Paleoceanographical Proxies Based on Deep-Sea Benthic Foraminiferal Assemblage Characteristics. Developments in Marine Geology, Volume 1: 263-325. DOI 10.1016/S1572-5480(07)01012-3

Joy, J.A., and Clark, D.L., 1977. The distribution, ecology and systematics of the benthic Ostracoda of the central Arctic Ocean. Micropaleontology, 23(2):129-154. doi:10.2307/1485329

Mazzini, I., 2005. Taxonomy, biogeography and ecology of Quaternary benthic Ostracoda (Crustacea) from circumpolar deep water of the Emerald Basin (Southern Ocean) and the South Tasman Rise (Tasman Sea). Senckenbergiana maritime, 35 (1): 1-119

Norman, A.M., 1865. Report on the Crustacea of the deep-sea dredging off the coast of Northumberland and Durham. Transactions of the Natural History Society of Northumberland, Durham and Newcastle-upon-Tyne, 1: 12-29.

Okada, Y. 1979. Stratigraphy and ostracoda from Late Cenozoic Strata of the Oga Peninsula, Akita Prefecture. Trans. Proc. Palaeont. Soc. Japan, N.S., 115: 143-173, pls.21-23.

Ozawa, H. 2003. Japan Sea ostracod assemblages in surface sediments: their distribution and relationships to water mass properties. Paleontological Research, 7(3): 257-274. Paleontological Society of Japan.

Ozawa, H. 2004. Okhotsk Sea ostracods in surface sediments: depth distribution of cryophilic species relative to oceanic environment. Marine Micropaleontology 53, 245-260

Ozawa, H. 2009. Middle Pleistocene Ostracods from the Naganuma Formation, Sagami Group, Central Japan: Significance of the Occurrence for the Bay Fauna Along the Northwest Pacific Margin. Paleontological Research, 13(3):231-244. The Palaeontological Society of Japan DOI: http://dx.doi.org/10.2517/1342-8144-13.3.231

Ozawa, H., T. Kamiya, H. Itoh, and S. Tsukawaki, 2004. Water temperature, salinity ranges and ecological significance of the three families of Recent cold-water ostracods in and around the 
427 Japan Sea. Paleontological Research, 8(1):11-28. The Palaeontological Society of Japan. DOI: $428 \quad 10.2517 /$ prpsj.8.11

429 Ozawa, H., T. Kamiya, 2005. Ecological analysis of benthic ostracods in the northern Japan Sea, 430 based on water properties of modern habitats and late Cenozoic fossil records. Marine 431 Micropaleontology 55 (2005) 255- 276.

432 Ozawa, H. and S. Tsukawaki, 2008. Preliminary report on modern ostracods in surface sediment 433 samples collected during R.V. Tansei-maru Cruise KT04-20 in the southwestern Okhotsk Sea 434 and the northeastern Japan Sea off Hokkaido, north Japan. Reprint from Annals of the Research 435 Institute of the Japan Sea Region Vol. 39, 31-47.

436 Poirier, R.K., T.M. Cronin, W.M. Briggs Jr., R. Lockwood, 2012. Central Arctic 437 paleoceanography for the last $50 \mathrm{kyr}$ based on ostracode faunal assemblages. Marine 438 Micropaleontology, 88-89C: 65-76.

439 Springer, A.M., McRoy, C.P., and Flint, M.V., 1996. The Bering Sea Green Belt: shelf-edge 440 processes and ecosystem production. Fish. Oceanogr., 5(3-4):205-223. doi:10.1111/j.1365$441 \quad$ 2419.1996.tb00118.x

442 Stabeno, P.J., Schumacher, J.D., and Ohtani, K., 1999. The physical oceanography of the Bering 443 Sea. In Loughlin, T.R., and Ohtani, K. (Eds.), Dynamics of the Bering Sea: A Summary of 444 Physical, Chemical, and Biological Characteristics, and a Synopsis of Research on the Bering 445 Sea: Fairbanks (Univ. Alaska Sea Grant), 1-28.

446 Stepanova, A., Taldenkova, E., Bauch, H.A., 2003. Recent Ostracoda from the Laptev Sea 447 (Arctic Siberia): species assemblages and some environmental relationships. Mar.

448 Micropaleontol. 48, 23- 48.

449 Swain, F., J.M. Gilby, 1974. Marine Holocene Ostracoda from the Pacific Coast of North and 450 Central America. Micropaleontology, Vol. 20, No. 3, pp. 257-353.

451 Tabuki, R., 1986. Plio-Pleistocene Ostracoda from the Tsugaru Basin, North Honshu, Japan.

452 University of Ryukyus Repository, p. 27-120)

453 Takahashi, K., Ravelo, A.C., Alvarez Zarikian, C.A., and the Expedition 323 Scientists, 2011.

454 Proc. IODP, 323: Tokyo (Integrated Ocean Drilling Program Management International, Inc.).

455 doi:10.2204/iodp.proc.323.2011

456 Tanaka, S., and Takahashi, K., 2005. Late Quaternary paleoceanographic changes in the Bering 457 Sea and the western subarctic Pacific based on radiolarian assemblages. Deep-Sea Res., Part II, 458 52(16-18):2131-2149. doi:10.1016/j.dsr2.2005.07.002. 
Tanaka, G., Y. Hasegawa, 2013. Miocene Ostracods from the Itahana Formation in the Tomioka District, Gunma Prefecture, Central Japan: Paleoenvironmental Significance and Systematics. Paleontological Research, 17(2):138-172. http://dx.doi.org/10.2517/1342-8144-17.2.138.

Teraishi, A., Suto, I., Onodera, J., and Takahashi, K., 2014. Diatom, silicoflagellate and ebridian biostratigraphy and paleoceanography in IODP 323 Hole U1343E at the Bering slope site. DeepSea Research II, http://dx.doi.org/10.1016/j.dsr2.2013.03.026

Whatley, R., and Coles, G., 1987. The late Miocene to Quaternary Ostracoda of Leg 94, Deep Sea Drilling Project. Rev. Esp. Micropaleontol., 19:33-97.

Whatley, R.C. and Eynon, M.P. 1996. Four new Arctic deepwater ostracod species from East Greenland. In Keen, M.C. (Ed.) Proceedings of the 2nd European Ostracodologists MeetinR, University of Glasgow, UK, 23-27 July 1993, 195-200.

Whatley, R.C., M. Eynon and A. Moguilevsky, 1998. The depth distribution of Ostracoda from the Greenland Sea. Journal of Micropalaeontology, 17: 15-32

Yamada, K., T. Irizuki, Y. Tanaka, 2002. Cyclic sea-level changes based on fossil ostracode faunas from the Upper Pliocene Sasaoka Formation, Akita Prefecture, northeast Japan. Palaeogeography, Palaeoclimatology, Palaeoecology 185:115-132

Yasuhara, M., Cronin, T.M. 2008. Climatic influences on deep-sea ostracode (crustacea) diversity for the last three million years. Ecology, 89(11) Supplement, 2008, pp. S53-S65

Yasuhara, M. and H. Okahashi (in press). Late Quaternary deep-sea ostracode taxonomy of the eastern North Atlantic Ocean. Journal of Micropalaeontology.

Yasuhara, M., H. Okahashi, and T.M. Cronin, 2009. Taxonomy of quaternary deep-sea ostracods from the western North Atlantic Ocean. Palaeontology, Vol. 52, Part 4, 2009, pp. 879-931.

Yasuhara, M., T.M. Cronin, G. Hunt, and D.A. Hodell, 2009. Deep-sea ostracods from the South Atlantic sector of the Southern Ocean during the last 370,000 years. J. Paleont., 83(6), pp. 914930.

Yasuhara, M., G. Hunt, T.M. Cronin, N. Hokanishi, H. Kawahata, A. Tsujimoto, M. Ishitake, 2012. Climatic forcing of Quaternary deep-sea benthic communities in the North Pacific Ocean. Paleobiology, 38(1):162-179.

Zhao, Q., R.C. Whatley, B. Zhou, 2000. The taxonomy and distribution of recent species of the ostracod genus Cytheropteron in the South China Sea. Revista Española de Micropaleontología, 32(2), 259-281. 
Table 1. Drilling results summary for Expedition 323 sites.

\begin{tabular}{|c|c|c|c|c|c|}
\hline IODP Site & Coordinates & $\begin{array}{l}\text { Water depth } \\
\text { (m) }\end{array}$ & $\begin{array}{l}\text { Penetration } \\
\text { depth } \\
\text { (m) }\end{array}$ & Age (Ma) & $\begin{array}{c}\text { Average } \\
\text { sedimentation } \\
\text { rate }(\mathrm{cm} / \mathrm{ky})\end{array}$ \\
\hline \multicolumn{6}{|c|}{ Bering Slope } \\
\hline U1344 & $\begin{array}{l}59^{\circ} 03.00^{\prime} \mathrm{N} \\
179^{\circ} 12.20^{\prime} \mathrm{W}\end{array}$ & 3171 & 745 & $0-1.9$ & 45 \\
\hline U1343 & $\begin{array}{c}55^{\circ} 33.39^{\prime} \mathrm{N}, \\
175^{\circ} 48.95^{\prime} \mathrm{W}\end{array}$ & 1950 & 744 & $0-2.4$ & 31 \\
\hline \multicolumn{6}{|c|}{ Umnak Plateau } \\
\hline U1339 & $\begin{array}{c}54^{\circ} 40.20^{\prime} \mathrm{N} \\
169^{\circ} 58.90^{\prime} \mathrm{W}\end{array}$ & 1868 & 200 & $0-0.8$ & 28 \\
\hline \multicolumn{6}{|c|}{ Bowers Ridge } \\
\hline U1340 & $\begin{array}{c}53^{\circ} 24.00^{\prime} \mathrm{N} \\
179^{\circ} 31.29^{\prime} \mathrm{W}\end{array}$ & 1294 & 604 & $0-5$ & 12 \\
\hline U1341 & $\begin{array}{l}54^{\circ} 24.00^{\prime} \mathrm{N} \\
179^{\circ} 00.49^{\prime} \mathrm{E}\end{array}$ & 2139 & 600 & $0-4.3$ & 14 \\
\hline U1342 & $\begin{array}{l}54^{\circ} 49.70^{\prime} \mathrm{N} \\
176^{\circ} 55.02^{\prime} \mathrm{E}\end{array}$ & 818 & 47.3 & $0-\sim 1$ & 3.6 \\
\hline
\end{tabular}


Table 2. List of ostracod taxa determined at the Bering Sea sites.

\begin{tabular}{|c|c|c|}
\hline Ostracod taxa & Illustration in this paper & Reference \\
\hline $\begin{array}{l}\text { Argilloecia toyamaensis Ishizaki } \\
\text { and Irizuki }\end{array}$ & Pl. 1, Figs, 11a-b & Ozawa (2004): pl.1, fig. 7 \\
\hline Bradleya mesembrina & P1. 2, Fig. 2 & Mazzini (2005): figs. 47A-K, 48B \\
\hline Cluthia sp. & Pl. 1, Fig. 10 & $\begin{array}{l}\text { Yasuhara and Okahashi (in press): pl. } \\
14 \text {, figs. G-H }\end{array}$ \\
\hline Cytheropteron sp. A & Pl. 1, Figs. 1-2 & \\
\hline Cytheropteron sp. B & P1. 1, Fig. 3 & $\begin{array}{l}\text { Strongly resembles C. massoni Whatley } \\
\text { and Coles [Whatley and Coles (1987): } \\
\text { pl.2, figs. 15-17]; similar to C. hanaii } \\
\text { Ishizaki [Ishizaki (1981): pl. 12, figs. 1- } \\
\text { 4, pl. 13, figs 8-9] }\end{array}$ \\
\hline Cytheropteron sp. C & P1. 1, Fig. 4 & \\
\hline Cytheropteron sp. D & P1. 1, Fig. 5 & $\begin{array}{l}\text { Similar to } C \text {. haydenensis Brouwers } \\
\text { (Brouwers, 1994) }\end{array}$ \\
\hline $\begin{array}{l}\text { Cytheropteron sp. E } \\
\text { Eucythere sp. }\end{array}$ & $\begin{array}{l}\text { Pl. 1, Fig. } 6 \\
\mathrm{n} / \mathrm{a}\end{array}$ & \\
\hline Eucytherura sp. & Pl. 2, Figs. 8a-c & $\begin{array}{l}\text { Similar to Eucytherura pacifica Ayress } \\
\text { et al. (1995) }\end{array}$ \\
\hline $\begin{array}{l}\text { Fallacihowella sp. A sensu } \\
\text { Mazzini }\end{array}$ & Pl. 2, Fig. 1 & Mazzini (2005): p. 56, fig. 31 \\
\hline Hemicytherura sp. & Pl. 2, Fig. 6 & \\
\hline Krithe sawanensis Hanai & Pl. 1, Fig. 9a-b & $\begin{array}{l}\text { Ozawa et al. (2004): pl. 2, fig. } 18 . \\
\text { Ozawa and Kamiya (2005): pl. 1, fig. } 5 .\end{array}$ \\
\hline Loxoconchidea sp. & Pl. 2, Figs. 10a-b & $\begin{array}{l}\text { Similar to L. dolgoiensis Brouwers: } \\
\text { Brouwers (1993): pl. 15, figs. 4-16. } \\
\text { Irizuki et al. (2007): p. } 427 \text {, fig. } 6.13 \text {. }\end{array}$ \\
\hline $\begin{array}{l}\text { Microcythere mediostriata (Joy } \\
\text { and Clark) }\end{array}$ & Pl. 1, Fig. 7 & \\
\hline Munseyella melzeri Brouwers & Pl. 2, Fig. 3a-b & $\begin{array}{l}\text { Brouwers (1990): pl. 6, figs. 9-15; pl. } 7 \text {, } \\
\text { figs. } 2,3\end{array}$ \\
\hline Munseyella ristveti Brouwers & Pl. 2, Fig. 4 & $\begin{array}{l}\text { Brouwers (1990): pl. 6, figs. 16-18; pl. } \\
\text { 7, fig. } 4\end{array}$ \\
\hline Palmoconcha sp. & Pl. 2, Fig. 7 & \\
\hline Pseudocythere caudata Sars & Pl. 1, Fig. 8 & Yasuhara et al. (2009): pl. 4, figs. 7-12 \\
\hline Robertsonites sp. & Pl. 2, Fig. 5 & $\begin{array}{l}\text { Similar to } R \text {. hanaii Tabuki: Tabuki } \\
\text { (1986): pl. 13, figs. } 1-12\end{array}$ \\
\hline
\end{tabular}


Table 3. Ostracod range chart for Site U1344. Below: samples from other Expedition 323 sites where ostracods were found.

\begin{tabular}{|c|c|c|c|c|c|c|c|c|c|c|c|c|c|c|c|c|c|c|c|c|c|c|c|c|}
\hline $\begin{array}{l}\text { Core Sample: Site, Hole, } \\
\text { Core, Section, Interval } \\
\text { (cm) }\end{array}$ & $\begin{array}{c}\text { Core Depth } \\
\text { (m CSF) }\end{array}$ & Age & 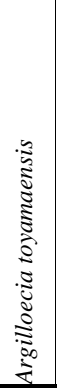 & 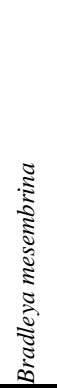 & 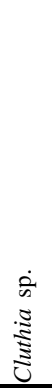 & 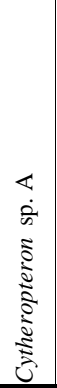 & 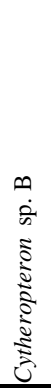 & 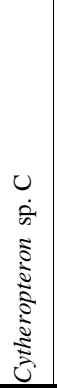 & 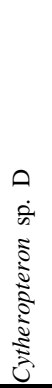 & 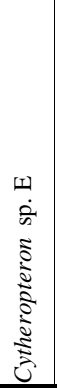 & 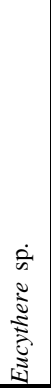 & 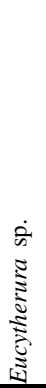 & 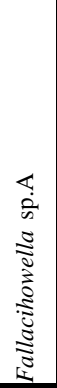 & 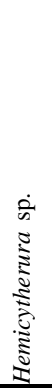 & 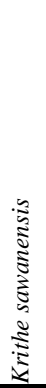 & 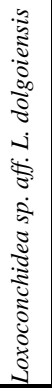 & 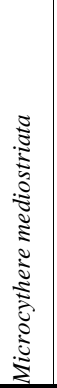 & 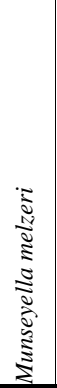 & 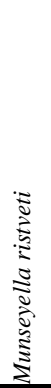 & 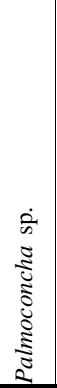 & $\begin{array}{l}\dot{1} \\
\text { के } \\
\tilde{0} \\
\stackrel{0}{0} \\
0\end{array}$ & 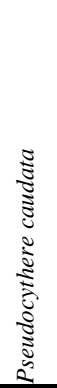 & 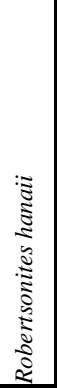 & 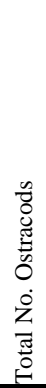 \\
\hline \multicolumn{25}{|l|}{ Site U1344 } \\
\hline U1344A__1H2_125 & 2.76 & \multirow{17}{*}{$\mathrm{L}$} & & & & & & & & & & & & & 2 & & & & & & & & & 2 \\
\hline U1344A__1H4_129 & 5.8 & & & & & & & & & & & & & & & & & 2 & & & & & & 2 \\
\hline U1344A_2H2_131 & 11.92 & & & & & & & & & & & & 1 & & & & & & & & & & & 1 \\
\hline U1344A_2H4_140 & 15.01 & & & & & & & & & & & & & & & & & & & & & & & \\
\hline U1344A_3H2_131 & 21.42 & & & & & & & & & & & & & & & & & & & & & & & \\
\hline U1344A__3H4_140 & 24.51 & & & & & & & & & & & & & & & & & & & & & & & \\
\hline U1344A__3HCC & 28.7 & & 1 & & 1 & & & & & & & & & & 1 & & & & & & & & & 3 \\
\hline U1344A_4H2_131 & 30.92 & & & & & & & & & & & & & & & & & & & & & & & \\
\hline U1344A_4H4_140 & 34.01 & & & & & & & & & & & & & & & & & & & & & & & \\
\hline U1344A_5H2_139 & 39.5 & & & & & & & & & & & & & & & & & & & & & & & \\
\hline U1344A_5H4_137 & 42.5 & & & & & & & & & & & & & & & & & & & & & & & \\
\hline U1344A_5HCC & 47.58 & & & & & & & & & & & 1 & & & & & & & & & & & & 1 \\
\hline U1344A_6H2_120 & 49.73 & & & & & & & & & & & & & & & & & & & & & & & \\
\hline U1344A__6H4_140 & 52.93 & & & & & & & & & & & & & & & & & & & & & & & \\
\hline U1344A_7H2_122 & 58.93 & & & & & & & & & & & & & & & & & & & & & & & \\
\hline U1344A_7H3_148 & 60.68 & & & & & & & & & & & & & & 1 & & & & & & & & & 1 \\
\hline U1344A__7H4_140 & 62.11 & & & & & & & & & & & & & & & & & & & & & & & \\
\hline U1344A_8H2_116 & 67.84 & \multirow{2}{*}{$\begin{array}{l}\mathrm{a} \\
\mathrm{t}\end{array}$} & & & & & & & & & & & & & 2 & & & & & & & & & 2 \\
\hline U1344A_8H4_122 & 70.86 & & & & & & & & & & & & & & & & & & & & & & & \\
\hline U1344A__9H2_121 & 77.58 & & & & & & & & & & & & & & & & & & & & & & & \\
\hline U1344A_9H4_139 & 80.6 & $\mathrm{e}$ & & & & & & & & & & & & & & & & & & & & & & \\
\hline U1344A_9H5_144 & 82.14 & \multirow[b]{3}{*}{$\mathrm{P}$} & & & & & & & & & 1 & & & & 2 & & & & & & & & & 3 \\
\hline U1344A_10H2_122 & 87.61 & & & & & & & & & & & & & & & & & & & & & & & \\
\hline U1344A_10H4_140 & 90.79 & & & & & & & & & & & & & & & & & & & & & & & \\
\hline \begin{tabular}{|l|} 
U1344A_11H2_123 \\
\end{tabular} & 96.43 & \multirow{3}{*}{$\begin{array}{l}\mathrm{l} \\
\mathrm{e}\end{array}$} & 2 & & & & & & & & & & & & & & & & & & & & & 2 \\
\hline U1344A_11H4_128 & 99.5 & & & & & & & & & & & & & & & & & & & & & & & \\
\hline \begin{tabular}{|l|} 
U1344A_12H2_120 \\
\end{tabular} & 106.29 & & & & & & & & & & & & & & & & & & & & & & & \\
\hline \begin{tabular}{|l|} 
U1344A_12H4_124 \\
\end{tabular} & 109.25 & \multirow{2}{*}{$\mathrm{i}$} & & & & & & & & & & 2 & & & & & & & & & & & & 2 \\
\hline U1344A_13H2_121 & 115.86 & & & & & & & & & & & & & & & & & & & & & & & \\
\hline U1344A_13H4_131 & 118.95 & \multirow{2}{*}{ S } & & & & & & & & & & & & & & & & & & & & & & \\
\hline U1344D-14H-5_2.0 & 122.136 & & & & & & & & & & & & & & 1 & & & & & & & & & 1 \\
\hline U1344A_14H2_120 & 125.02 & $\mathrm{t}$ & & & & & & & & & & 2 & & & & & & & & & & & & 2 \\
\hline
\end{tabular}




\section{$493 \quad$ Figure captions}

494 Figure 1. Location of IODP Expedition 323 sites in the Bering Sea.

495 Figure 2. Ostracod stratigraphic distribution at Site U1344. The sedimentary record at Site

496 U1344 spans from $\sim 1.9$ Ma to the Present. The shaded area represents the Mid-Pleistocene

497 transition $(\sim 1.2 \mathrm{Ma}$ to $\sim 0.6 \mathrm{Ma})$, which corresponds to one of the most important steps in the 498 expansion of the Northern Hemisphere ice sheets. 


\section{Plate captions}

500 Plate 1. Scanning electron microscopy images of Bering Sea ostracods. All scale bars $=200$ 501 microns.

502

503

504

505

506

507

508

509

510

511

512

513

514

515

516
1-2: Cytheropteron sp. A. 1, right valve, external view, mudline sample from Hole U1342A. 2, carapace, external view, sample U1344A-14H3, $144 \mathrm{~cm}$.

3: Cytheropteron sp. B. Right valve, external view, sample U1339C-8H3, $57 \mathrm{~cm}$.

4: Cytheropteron sp. C. Left valve external view, sample U1341A-9HCC.

5: Cytheropteron sp. D. Left valve external view, sample U1339D-8H4, $82 \mathrm{~cm}$.

6. Cytheropteron sp. E. Carapace, left valve external view, mudline sample Site U1343.

7: Microcythere medistriata (Joy and Clark). Carapace, left valve external view, sample U1343E-9HCC.

8: Pseudocythere caudata Sars. Carapace, left valve external view, sample U1343A9HCC.

9: Krithe sawanensis Hanai. 9a: left valve, internal view, sample U1344A-7H3, 148 cm; 9b: carapace (left valve shown), sample U1344A-8H2, $116 \mathrm{~cm}$.

10: Cluthia sp. Left valve, sample U1344A-21H2, $110 \mathrm{~cm}$.

11. Argilloecia toyamaensis Ishizaki and Irizuki. 11a: left valve, sample U1344A-3HCC; 11b: right valve, sample U1344A-11H2, $123 \mathrm{~cm}$. 
517 Plate 2. Scanning electron microscopy images of Bering Sea ostracods. All scale bars $=200$

518 microns.

519 1: Fallacihowella sp. A. Right valve, sample U1344A-2H2, $131 \mathrm{~cm}$.

520

2: Bradleya mesembrina Mazzini. Right valve, sample U1341A-9HCC.

521

3: Munseyella melzeri Brouwers. 3a: Carapace, right valve shown, external view, sample

522 U1344A-23H4, $124 \mathrm{~cm}$; 3b: left valve, external view, sample U1344A-23H4, $124 \mathrm{~cm}$.

4: Munseyella ristveti Brouwers. Carapace, left valve shown, external view, mudline sample from Site U1343.

525

5: Robertsonites sp. Left valve, Site U1343.

526

6: Hemicytherura sp. Left valve, external view, sample U1344A-30X2, $140 \mathrm{~cm}$.

527

7: Palmoconcha sp. Left valve, external view, mudline sample from Site U1342.

528

8: Eucytherura sp. 8a: left valve, external view; 8b: right valve, external view, sample

529

530

U1344A-12H4, 124 cm (Late Pleistocene); 8c: carapace, right valve view, sample

U1344A-61X-2, $140 \mathrm{~cm}$ (Early Pleistocene).

531

9: Cluthia sp. Left valve, sample U1344A-21H2, $110 \mathrm{~cm}$.

532

10: Loxoconchidea sp. 10a: left valve, external view; 10b: right valve, external view, sample U1344A-58X2, $102 \mathrm{~cm}$. 
535 APPENDIX

536 Systematic Paleontology

537

Class Ostracoda Latreille 1802

538

Subclass Myodocopa Sars 1866

539

Order Halocyprida Dana 1853

540

Suborder Cladocopina Sars 1866

541

Superfamily Polycopidea Sars 1866

542

Family Polycopidae Sars 1866

543

Genus Polycope Sars 1866

544

Polycope sp.

545 Remarks: Polycope sp. (2 specimens) was found at Site U1344 (Sample U1344D-19H7, $2 \mathrm{~cm}$

546 (172.7 m CSF-A). Distribution: Late Pleistocene.

547

548

Order Podocopida Sars 1866

549

Suborder Cypridocopina Jones, 1901

550

Superfamily Pontocypridoidea Müller 1894

551

Family Pontocyprididae Müller 1894

552

Genus Argilloecia Sars 1866 
P1. 1, Figs, 11a, b

556 Remarks: Argilloecia toyamaensis was found at Site U1344, in samples U1344A-3HCC (28.7 m 557 CSF-A) and U1344A-11H2, $123 \mathrm{~cm}$ (96.43 m CSF-A). Argilloecia toyamaensis is a cryophilic 558 species commonly found in modern and Pleistocene outer shelf to slope sediments in the 559 Okhotsk Sea and northern Japan Sea (Ozawa, 2004). Distribution: Late Pleistocene.

560

568 Remarks: 1 carapace of Pseudocythere caudata was found in core catcher sample U1343A569 9HCC (84.1 m CSF-A). Distribution: Late Pleistocene 
576 Remarks: One recent specimen of Cytheropteron sp. A was found on the mudline sample from 577 Hole U1342A (818 m of water depth, Bowers Ridge, southern Bering Sea), and one fossil 578 carapace in Sample U1344A-14H3, $144 \mathrm{~cm}$, at Site U1344. The specimens of Cytheropteron sp. 579 A are juveniles, and may belong to Cytheropteron higashikawai Ishizaki (Ishizaki, 1981: pl. 12, 580 figs. 6-9), but they lack the denticulate posterior edge in the alar process. Remarks: One specimen of Cytheropteron sp. B' was found in sample U1339C-8H3, $57 \mathrm{~cm}$ at

584 Site U1339. The Bering Sea specimen is a small elongate species of Cytheropteron with a 585 delicately punctate surface ornamentation. It has a long and relatively straight with a median 586 concavity dorsal margin. A short arcuate ridge occurs mid-dorso-laterally and this branches out 587 to a second ridge that parallels the dorsal margin. The alae are short, and directed slightly 588 backward with sharp leading edge and weak zigzag ridge at the base. Cytheropteron sp. B 589 exhibits very strong resemblance to Cytheropteron massoni Whatley and Coles from the North 590 Atlantic (Whatley and Coles, 1987: pl.2, figs. 15-17). This species is also similar to 
591 Cytheropteron hanaii Ishizaki from the East and South China Seas (Ishizaki, 1981; Zhao et al., 592 2000).

595 Remarks: One specimen of Cytheropteron sp. C was found at Site U1341, in core catcher sample 596 U1341A-9HCC. This species is similar to Cytheropteron demenocali Yasuhara, Okahashi and 597 Cronin, from the western North Atlantic (Yasuhara et al., 2009: pl. 9, figs 1-10), and to 598 Cytheropteron porterae Whatley and Coles from the subpolar North Atlantic (Whatley and 599 Coles, 1987).

602 Remarks: Only one specimen of Cytheropteron sp. D was found at Site U1339 in the Umnak 603 Plateau, in sample U1339D-8H4, $82 \mathrm{~cm}$. The specimen resembles Cytheropteron haydenensis 604 Brouwers, 1994 from the Gulf of Alaska by the weak, smooth ventral ridge and fine reticulation. 605 Morphologically similar forms include C. arcticum Neale and Howe (Quaternary, North 606 Atlantic) and C. champlainum Cronin (upper Pleistocene, northwest Atlantic). In the Gulf of 607 Alaska C. haydenensis is found in the sublittoral region (Brouwers, 1994). Distribution: Late 608 Pleistocene. 
611 Remarks: One carapace of Cytheropteron sp. B was found in the mudline sample from Site

612 U1343 and another one in sample U1339D-8H4, $82 \mathrm{~cm}$, at Site U1339 (Table 3).

613

614

615

616

617

618

619

620

621

622

623

624

625

626

627

628

629

630
Genus Eucytherura Müller, 1894

\section{Eucytherura sp.}

P1. 2, Figs. 8a, b, c

Remarks: Found only at Site U1344. The late Pleistocene forms (Plate 2, Figs. 8a-b) are slightly different in the posterior end to the early Pleistocene form (Plate 2, Fig. 8c). Seven specimens, including 3 carapaces, of Eucytherura sp. were found at Site U1344 in samples U1344A-5HCC, U1344A-12H4, 124 cm; U1344A-14H2, 120 cm; U1344A-61X2, $140 \mathrm{~cm}$ ) (Table 3). The Bering Sea species is subrhomboidal in lateral outline, tumid posteroventrally, and coarsely reticulated. It lacks the eye tubercules and it has primary muri aligned sub-parallel to anterior margin. Eucytherura sp. is somewhat similar to Eucytherura pacifica Ayress, Whatley, Downing and Millson 1995 from the southwestern Pacific and Indian Ocean.

Genus Hemicytherura Elofson, 1941

Type species Cythere cellulosa Norman, 1865, p. 22, pl. 5, figs. 17, 20, pl. 6, fig. 17

Hemicytherura sp. P1. 2, Fig. 4

Remarks: a single valve was found in Sample U1344A-30X2, $140 \mathrm{~cm}$. Distribution: mid Pleistocene. 
Eucythere sp.

634 Remarks: a single specimen of Eucythere sp. was found in Sample U1344A-9H5, $144 \mathrm{~cm}$.

635

636

637

638

639

640

Type species. Cythere cluthae Brady, Crosskey and Robertson 1874

641

Remarks: Cluthia sp. was found at Site U1344 in samples 3HCC (at 28.7 m CSF) and U1344A-

$64221 \mathrm{H} 2,110 \mathrm{~cm}$ (at $191.48 \mathrm{~m} \mathrm{CSF}$ ). This taxon was referred to as Nannocythere delicata (Whatley

643 and Eynon 1995) and Nannocythere sp. by Whatley et al. (1998), Didié and Bauch (2000) and

644 Alvarez Zarikian (2009), however, there are some problems with the nomenclature. For this

645 reason here I follow the taxonomy of Yasuhara and Okahashi (in press) for its generic

646 classification. Distribution: Late Pleistocene.

647

648

Family Loxoconchidae Sars, 1926

649 
Palmoconcha sp.

653 Remarks: a single specimen of this species was found on a mudline sample from Site U1342 654 (818 m of water depth) on the Bowers Ridge, southern Bering Sea. The specimen, illustrated in

655 plate 2, figure 8, matches the diagnostic description for the genus Palmoconcha, a loxoconchoid 656 genus with valves having markedly flattened flange-like terminal marginal areas and coarsely 657 pitted or reticulate general surface (Swain and Gilby, 1974). Species of this genus are known 658 from the sublittoral to upper bathyal zones.

664 Remarks: a fragmented carapace was found in Sample U1344A-58X2, 102 cm (543 m CSF). 665 Loxoconchidea sp. is very similar to Loxoconchidea dolgoiensis Brouwers from the Gulf of 666 Alaska (Brouwers, 1993), but because of the fragmented valves it wasn't possible to confidently 667 assign the Bering Sea specimen to L. dolgoiensis. Distribution: Lower Pleistocene: central Japan; 668 Pleistocene through Holocene in northeast Gulf Alaska where it is found from middle to outer 669 shelf, to the upper slope. 
676 Remarks: Krithe is the most abundant and widespread ostracod genus in the deep sea. Likewise, 677 it is the most common genus in the Bering Sea samples. Only Krithe sawanensis was identified 678 in the present study. K. sawanensis is common in lower shelf to continental slope areas of the 679 northwestern Pacific (Ozawa 2003). K. sawanensis is morphologically similar to Krithe 680 burkholderi Brouwers from the Gulf of Alaska (Brouwers, 1990) or Krithe glacialis (Brady, 681 Crosskey and Robertson) from the Arctic and North Atlantic Ocean (Whatley et al. 1998; 682 Stepanova et al. 2003). 
690 Remarks: M. medistriata was found at Site U1344, sample U1344A-38X2, $140 \mathrm{~cm}$ (one 691 carapace), and at Site U1343, core catcher sample U1343-9HCC (one valve). This is the first 692 report of this species outside of the Arctic Ocean (Joy and Clark, 1977; Briggs, 1997; Poirier et 693 al., 2012; and Cronin et al., 2013) and the subpolar North Atlantic (Alvarez Zarikian, 2009). This 694 species occurs in significant numbers in the western Arctic Ocean, where it is characteristic of 695 intermediate water masses (Poirier et al., 2012). M. medistriata is also considered to possibly be 696 linked to increased sea ice cover (Cronin et al., 2013).

703 Remarks: Found at Sites U1343 and U1344. Material: two carapaces and three single valves. 704 This species was described by Brouwers (1990) from the Gulf of Alaska. M. melzeri is 705 characterized by weak ornament ridges, $\mathrm{V}$-shape ridge in anteromedian region, robust posterior 706 marginal denticles and convergent posterior. It also closely resembles Munseyella sp. 3 from the 707 Okhotsk Sea (Ozawa and Tsukawaki, 2008: pl. 2, fig. 10). In the Gulf of Alaska, this species is 708 found in Pleistocene through Holocene sediments in the middle to outer sublittoral zone 
709 (Brouwers, 1990). In the Okhotsk Sea, it is found on shelf sediments at $\sim 100$ m water depth

710 (Ozawa and Tsukawaki, 2008). Distribution: Mid to Late Pleistocene at Site U1344.

713 Remarks: only one carapace was found at Site U1343. M. ristveti was described from Holocene 714 deposits from the middle to outer shelf of the Gulf of Alaska (Brouwers, 1990).

721 Remarks: two specimens were found in Sample U1344A-20H4, $130 \mathrm{~cm}$, and one in Sample U1341A-9HCC. B. mesembrina was originally described from Holocene sediments in the South 723 Tasman Rise at depths of 1636-3022 m (Mazzini, 2005), and its previously known distribution 724 extends to Late Pleistocene and Recent sediments in Antarctic and sub-Antarctic zones of the 725 Southern Ocean at a depth range of 231-4420 m (Brandão and Päplow, 2011). This is the first 726 record of B. mesembrina in the North Pacific. Distribution: Late Pleistocene in the Bering Sea. 
732 Remarks: Fallacihowella sp. A sensu Mazzini 2005 is the second most abundant ostracod 733 species in the Bering Sea samples (12 specimens). It was found at Sites U1339 (Umnak Plateau), 734 U1341 (Bowers Ridge) and U1344. The specimens found in the Bering Sea are similar to 735 Fallacihowella sol Jellinek and Swanson (Jellinek and Swanson, 2003; pl. 34 figs. 1-10; pl. 35 736 figs. 1-6), but it is identical to Mazzini (2005)'s Fallacihowella sp. A from the Tasman Sea and 737 the Southern Ocean. Mazzini (2005) indicates that Fallacihowella sp. A differs from F. sol 738 because of its larger dimensions. Moreover, Fallacihowella sp. A is considered to be adapted to 739 narrow ecological gradients, living in diatom/radiolarian ooze with a very low carbon content 740 (Mazzini, 2005), the sedimentological setting as in the Bering Sea. This is the first record of $B$. 741 mesembrina in the North Pacific. Distribution: mid Pleistocene to Holocene. 
Remarks: a juvenile valve of Robertsonites sp. was found at Site U1343. The species of Robertsonites at Site U1343 is similar to R. hanaii Tabuki (see Tabuki, 1986: pl. 13, figs. 1-12), but the latter has a coarser reticulate surface than the Bering Sea form. Robertsonites sp. differs from $R$. tuberculata (Sars) by the lack of posterodorsal and posteroventral nodes characteristic of the latter species (Hazel, 1967: pl. 6, figs. 1-3). The genus Robertsonites is widely distributed in high latitude seas of the Northern Hemisphere and it is common in fossil ostracod faunas in Plio-Pleistocene deposits in Japan (Ikeya and Cronin, 1993). The genus is common in ostracod assemblages in muddy 755 sediments of the lower continental shelf and slope areas of the present day Japan Sea, where the water temperature remains at 0-5 degrees Celsius throughout the year (e.g. Ozawa, 2003; Ozawa and Kamiya, 2005). 


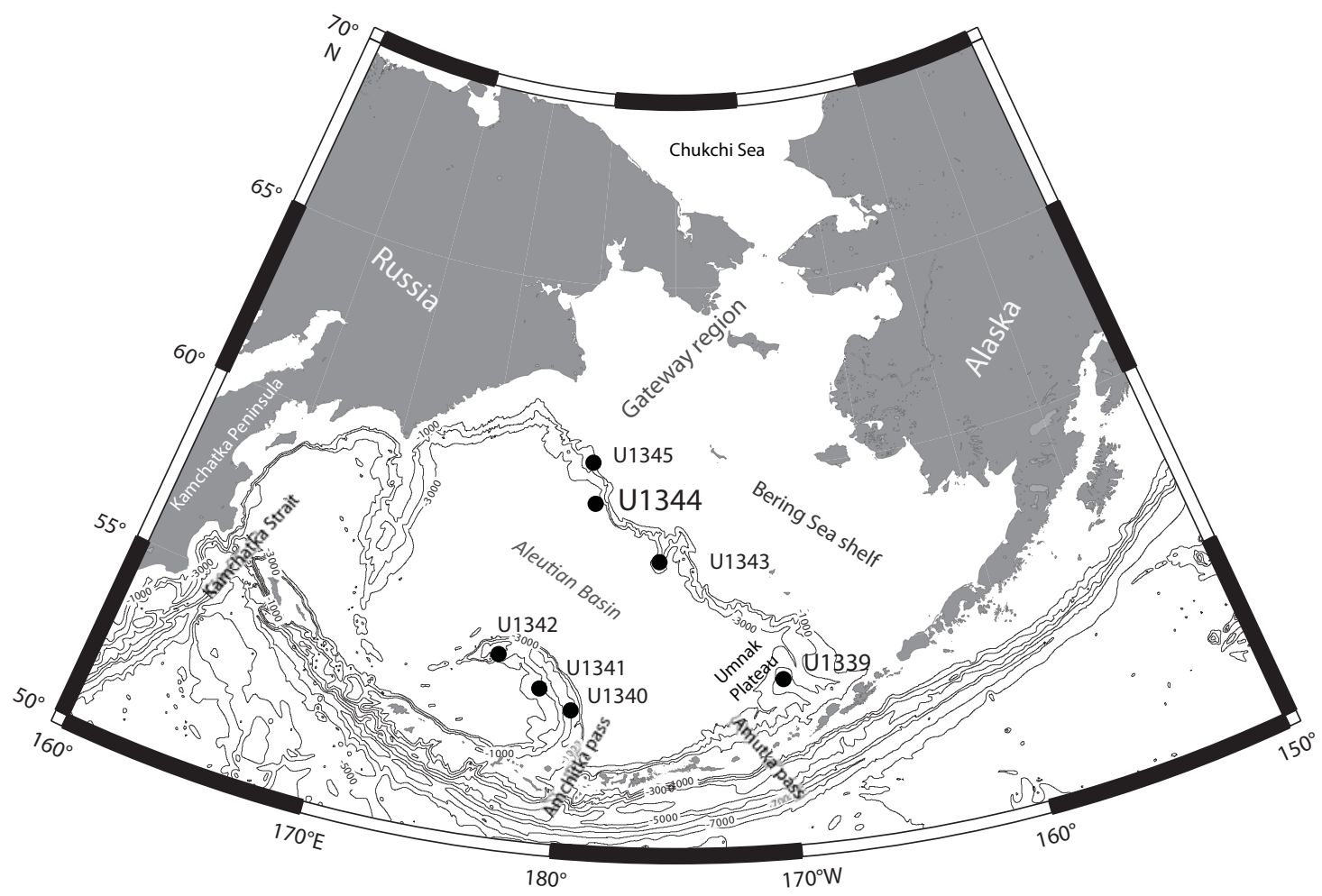

Figure 1. 


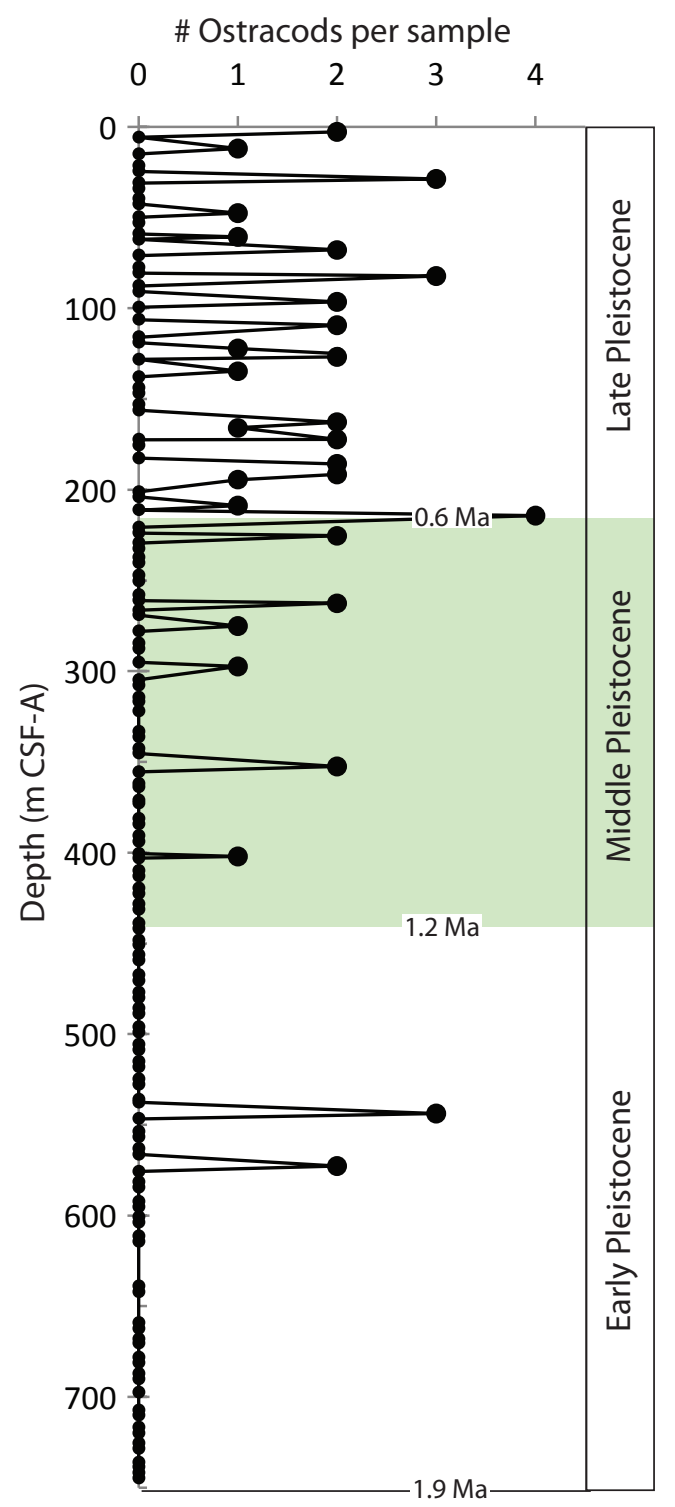

Figure 2. 


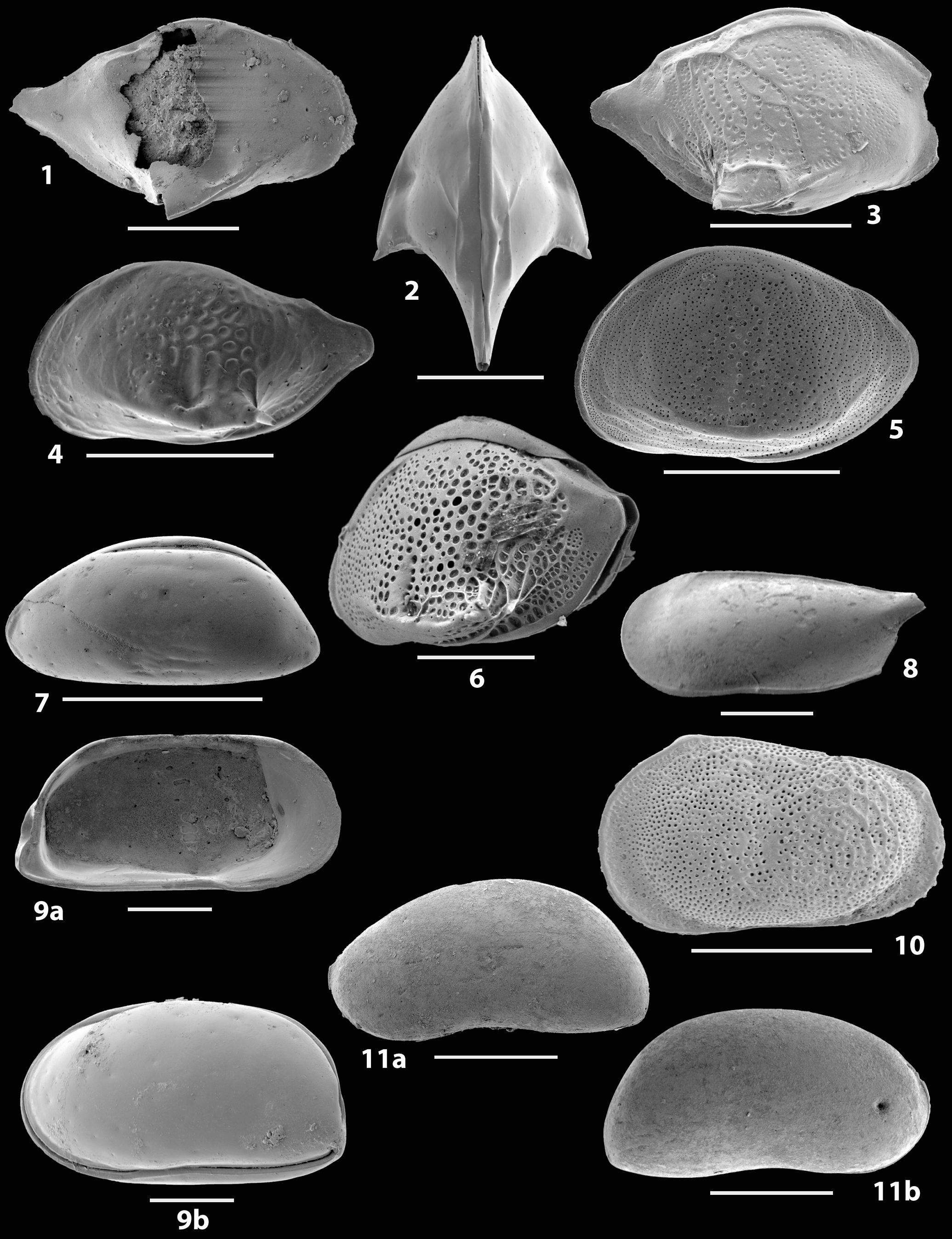




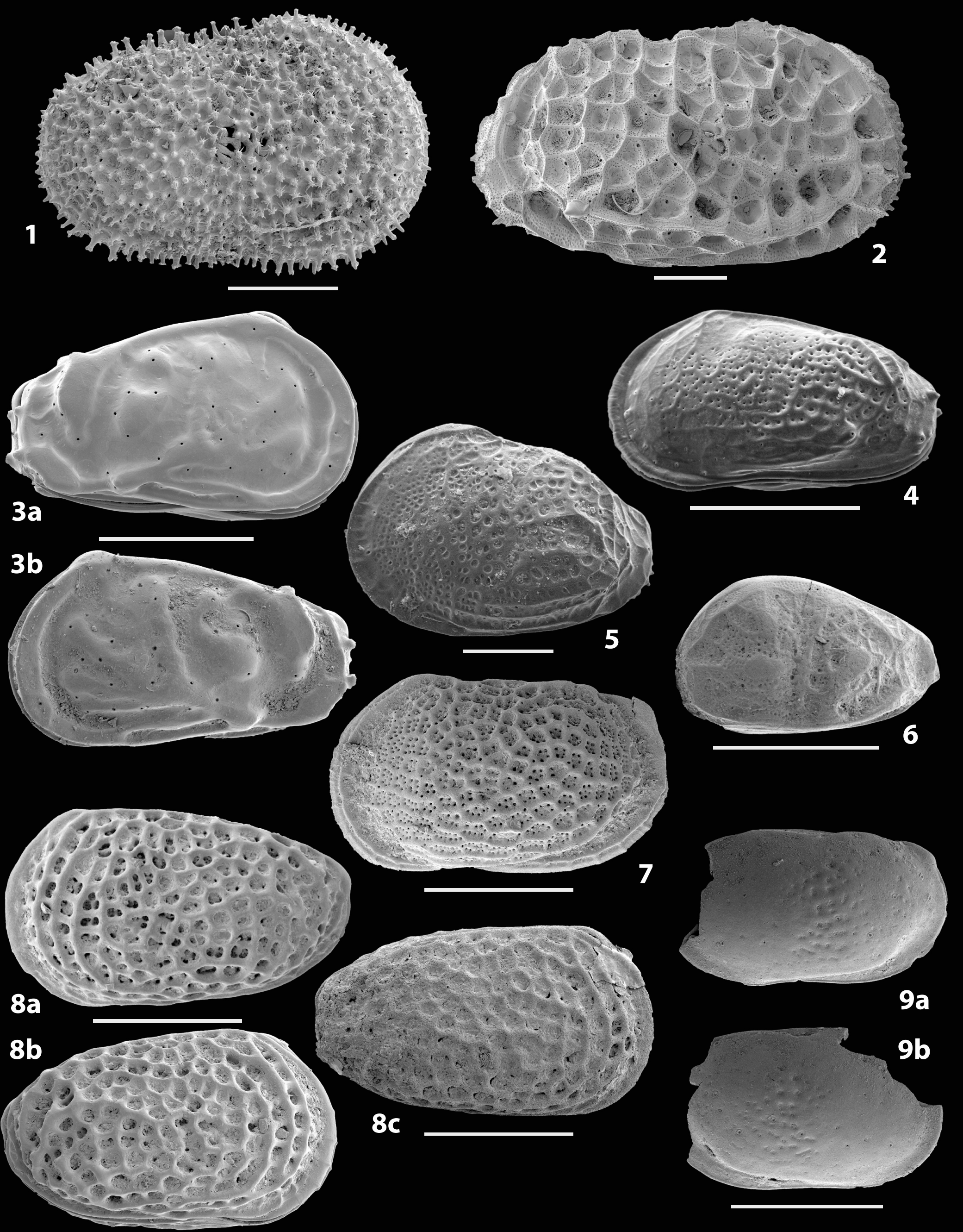

